International Journal of

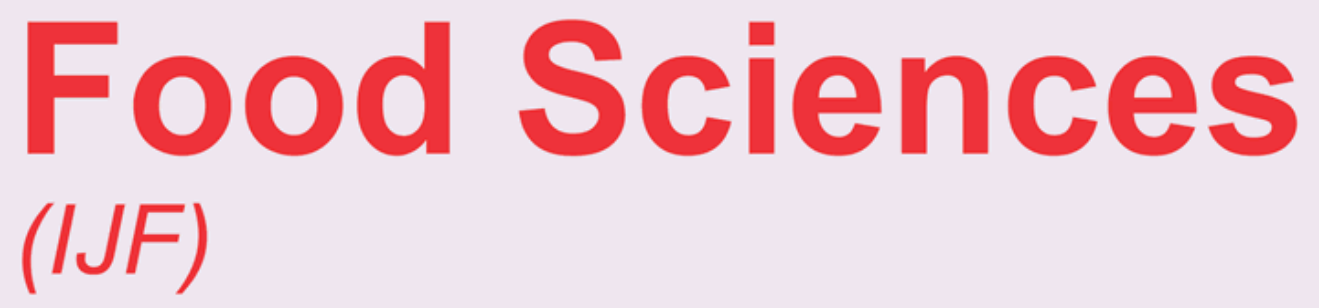

\title{
EVALUATION OF PROXIMATE COMPOSITION AND SELECTED PHYSICO-CHEMICAL PROPERTIES OF BUTTERNUT SQUASH
}

\author{
(CUCUBITA MOSCHATA)
}

KONADU MARY, ENOCH ASSILIDJOE, Dr. MARY-MAGDALENE PEDAVOAH AND

DANIEL K. QUANSAH 


\title{
EVALUATION OF PROXIMATE COMPOSITION AND SELECTED PHYSICO- CHEMICAL PROPERTIES OF BUTTERNUT SQUASH (CUCUBITA MOSCHATA) \\ ${ }^{1}$ Konadu Mary, \\ Department of Applied Chemistry and Biochemistry, Faculty of Applied Sciences UNIVERSITY FOR DEVELOPMENT STUDIES (2015). Corresponding Author's E-mail:
}

${ }^{2}$ Noch Assilidjoe,

Department of Applied Chemistry and Biochemistry, Faculty of Applied Sciences UNIVERSITY FOR DEVELOPMENT STUDIES (2015).

${ }^{3}$ Dr. Mary-Magdalene Pedavoah

Department of Applied Chemistry and Biochemistry, Faculty of Applied Sciences UNIVERSITY FOR DEVELOPMENT STUDIES (2015).

${ }^{3}$ Daniel K. Quansah

Department of Applied Chemistry and Biochemistry, Faculty of Applied Sciences UNIVERSITY FOR DEVELOPMENT STUDIES (2015).

\begin{abstract}
Purpose: This study sought to evaluate of proximate composition and selected physicochemical properties of butternut squash.

Methodology: Samples were chosen randomly from Northern part Ghana specifically Kukobila and data analyzed statistically. Oil was extracted using soxhlet extraction method.

Findings: Results showed that For the proximate analysis, fat content of the pulp was $1.16 \%$ and carbohydrate $72.70 \%$. The fibre content of the defatted seed residue was $5.59 \%$, ash $(6.86 \%)$ and protein $(49.20 \%)$. The acid value, saponification value, iodine value, peroxide value and free fatty acid were $3.42 \mathrm{mgKOH} / \mathrm{g}, 15.43 \mathrm{mgKOH} / \mathrm{g}, 21.08 \mathrm{gI} / 100 \mathrm{~g}, 2.50 \mathrm{meqO} / \mathrm{kg}$ and 1.71 respectively. The high oil content of the seeds coupled with fairly low acid value makes it suitable as edible oil, a food supplement and suggest its suitability for the production of paints, inks but not suitable for soap and biodiesel production
\end{abstract}

Unique contribution to theory, practice and policy: Farmers should avoid local consumption of butternut squash due to lack of knowledge on the potentials and uses; since its underutilized and cultivated mainly for export. More research should be carried out to convert Butternut squash into breakfast meals and baby feeds due to its high protein content and gluten free nature

Keywords: Pulp, nutritive, defatted, biodiesel, fibre, formulations, Cucurbita moschata, proximate composition, oil physicochemical properties 


\section{INTRODUCTION}

The current rate of population growth coupled with climate change leaves the world with little food to feed the masses; there is therefore the urgent need to identify and make use of neglected and under-utilized plant species for food production. Butternut squash is the most popular vegetable among the winter squash varieties. Butternuts are annual long trailing vines, usually cultivated in warmer climates of South and Central American. They produce edible fruits, flowers and seeds ${ }^{55}$.

It is cultivated in most tropical countries in Africa especially in Southern Africa. The fruit is popular for making pumpkin pie, sweets and desserts such as; steamed food flesh with granted coconut and sugar. In Zambia, ripe butternut flesh is dried for longer preservation. About $40 \%$ of the households in Zambia use butternut leaves as relish daily during the rainy season. In Cameroon and other parts of Central and West Africa, butternut squash is principally grown for the ripe seeds. The seeds are roasted with its shells, salted and eaten as snacks. The seed oil is edible and used as fuel. It has several medical applications in Thailand and China. Crushed fresh seeds are used as anthelmintic, and also used in treatment of skin infections and inflammations ${ }^{27}$.

In Ghana, butternut has recently been cultivated in the Upper East, Upper West and Northern Regions mainly for export. According to Ministry of Food and Agriculture (MOFA) butternut squash cultivation is a strategy to increase income and reduce poverty in Northern Ghana especially. It has now become an alternative crop for Volta farmers' too ${ }^{49}$. However, the local consumption and the use of this plant have not been encouraged until now.Butternut squash is a vigorous growing plant that takes 85 to 90 days to mature and it produces good uniform fruits weighing about 650 to $1000 \mathrm{gm}$. Among other cucurbits like courgettes, pumpkin and cucumbers, butternut squash is gaining preference because of its early maturity, its color that is appealing to the eyes of the customers, its long shelf life and small size that makes it attractive to consumer.

Moreover, it is a hardy crop, which is able to tolerate moderately harsh environmental conditions, resistant to many pests of cucurbits and can be grown well in small plots of land. It yields relatively good returns with minimal fertilizer inputs making it an appropriate crop as land subdivision continues in rural settings. The crop also has ready local and export market ${ }^{6}$ some growers in Western region of Kenya are expanding their production to meet increased local and export demand ${ }^{36}$. Although butternut was introduce recently in Ghana, most farmers are going into its cultivation but the local consumption has not caught up well in Ghana; as many people including the farmers make very little or no use of the produce. The produce are mainly exported, therefore there is the need to encourage local consumption. This will however be possible if adequate research and development is done to assess potential uses.

\section{MATERIALS AND METHOD}

\section{Sampling Collection}

Butternut fruits were sampled from the local farm at Kukobila near Tamale in the Northern region of Ghana. The fruits were chosen randomly at commercial maturity according to their similarity in color, size and the absence of surface defects.

\section{Sample preparation}

The butternut fruit (fig. 1) were peeled and the seeds (fig. 2) were extracted manually from the pulp. The flesh pulp was sliced into thin sizes and dried in the sun to remove all the moisture in it. The dry samples were grinded into powder and stored in a clean dry container until ready 
for use. The seeds were also dried for one week. The immature or broken seeds and foreign materials were removed and the rest stored in a clean air tight container in the dark until needed. The seeds were grinded in a grinder mill to produce the powdered form.

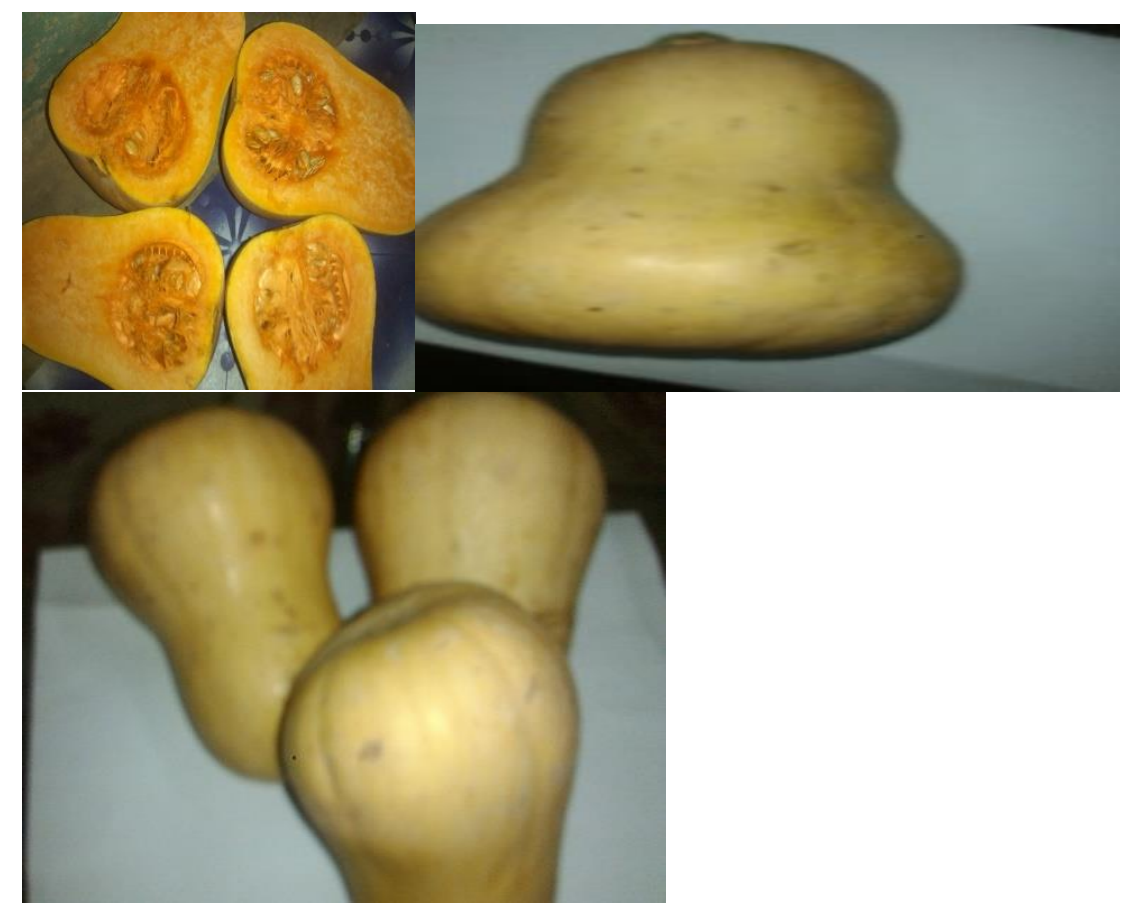

Figure 1: Photos of Butternut (Cucurbita moschata).

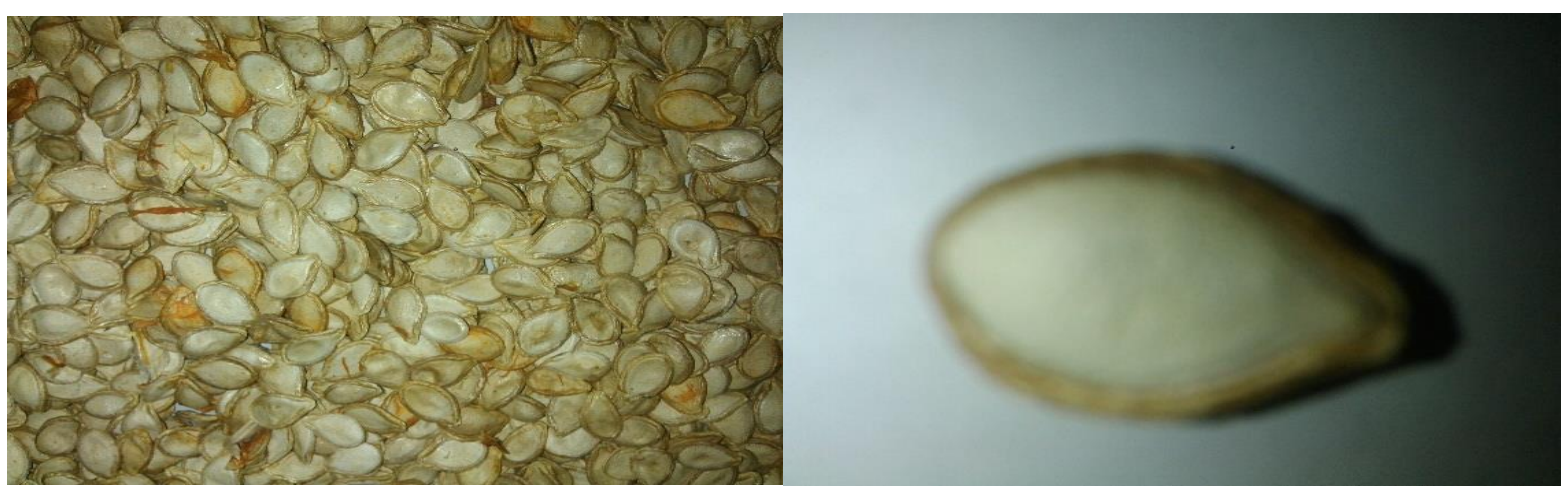

Figure 2: Photos of Butternut Seeds.

\section{Methods for preparing flour}

Cleaning and washing: Butternut squash fruits were washed with clean water in order to remove dirt and any unwanted materials.

Peeling: The fruits were peeled using a sharp knife due to its hard skin.

Drying: The fruits were sliced into two, seeds were removed and the fresh pulp was cut into thin sizes and dried in the sun for about one week.

Grinding: The dried pulp was grinded using a grinding mill into flour.

Proximate Analysis of fruit pulp, defatted seed residue and seeds 
Moisture, ash (AOAC method No. 945.18), fat (AOAC method No. 945.16) and crude protein (AOAC method No.920.53) were determined by the AOAC ${ }^{4}$. A factor of 6.25 was used for the conversion of nitrogen into crude protein. Carbohydrate content was calculated by subtracting the contents of all the measured components (moisture, ash, crude fat and crude protein) from total mass. All measurements were expressed on dry matter basis and reported as a mean $( \pm$ S.D) of triplicate analysis. Determination of crude fat or lipid content of the samples was done using Soxhlet (Cehmglass) type of the direct solvent extraction using petroleum ether (boiling range $60-80^{\circ} \mathrm{C}$ ) as solvent.

\section{Moisture Content Analysis}

A mass of $3.0 \mathrm{~g}$ of each sample was weighed into a dried and pre-weighed glass crucible (W1). Samples were dried in an oven at $105.2{ }^{\circ} \mathrm{C}$ overnight. The crucible was cooled at room temperature and weight taken as (W2).The moisture content was calculated using the formula;

$$
\% \text { moisture }=\frac{\mathrm{W} 1-\mathrm{W} 2}{\text { weight of sample }} \times 100 \%
$$

\section{Crude Ash Analysis}

A Cleaned empty crucible was placed in a muffle furnace for 30 minutes at $600{ }^{\circ} \mathrm{C}$, cooled and weighted (W1). A mass of $1.0 \mathrm{~g}$ of each sample was put in the crucible and weight noted (W2). The sample was ignited in the furnace at $600{ }^{\circ} \mathrm{C}$ for 3 hours. The appearance of grey white ash indicated complete oxidation of all organic matter in the samples. After ashing, the crucible was cooled and weighed (W3). The following formula was used to calculate the percentage ash.

$$
\% \text { ash }=\frac{\mathrm{W} 3-\mathrm{W} 1}{\text { weight ofsample }} \times 100 \%
$$

\section{Crude Fiber}

A mass of $2.0 \mathrm{~g}$ of the defatted samples was weighed and transferred into porous crucibles. Crucibles were placed into a Dosi- fiber unit and the valve at off position. A volume of 1.50 $\mathrm{ml}$ of pre-heated $\mathrm{H}_{2} \mathrm{SO}_{4}$ solution and some drops of acetone were added to prevent foaming. The cooling circuit and the heating element (power at $90 \%$ ) were turned on. Power was reduced to $30 \%$ when it started boiling and left for 10 minutes. The valves were opened to allow drainage of acid and rinsed with distilled water to completely remove all acid from the sample. The sample was dried in an oven at $150{ }^{\circ} \mathrm{C}$ for 1 hour and then at room temperature and weighed (W1). The Samples were then kept in a furnace at $55^{\circ} \mathrm{C}$ for $3-4$ hours. The samples were cooled and weighed again (W2). The crude fiber was calculated using the formula:

$$
\% \text { Crude fibre }=\frac{\mathrm{W} 1-\mathrm{W} 2}{\text { weight of sample }} \times 100 \%
$$

\section{Lipid}

Lipid content was estimated using TecatorSoxtec. A quantity of $2 \mathrm{~g}$ sample mixed was weighed into a thimble and covered with absorbent cotton, while $40 \mathrm{ml}$ of petroleum ether $\left(40-60{ }^{\circ} \mathrm{C}\right.$ Bpt) was pre-weighed cup. Both thimble and cup were attached to the extraction unit. The sample was extracted using ethanol for 30 minutes and rinsed for 50 minutes. The solvent was evaporated from the cup to the condensing column. Extracted fat (Appendix-VIII) in the cup was then place in an oven at $105^{\circ} \mathrm{C}$ for $1 \mathrm{~h}$ and cooled and weighed.

Percent fat was calculated as: 


$$
\% \text { Lipid }=\frac{[\text { initial Cup weight }- \text { Final Cup weight }]}{\text { weight of Sample }} \times 100
$$

\section{Crude protein Analysis}

Determination of total nitrogen (crude protein) was conducted using the Kjedahl method. The sample was digested in sulfuric acid using $\mathrm{CuSO}_{4}$ as a catalyst. $\mathrm{N}$ was converted into $\mathrm{NH}_{3}$, then distilled, trapped in boric acid and titrated with $\mathrm{H}_{2} \mathrm{SO}_{4}$.

A mass of $1 \mathrm{~g}$ of the sample was weighed into a digestion tube $(250 \mathrm{ml})$. Two tablets $\left(\mathrm{CuSO}_{4}\right)$ were added as a catalyst. A volume of $13 \mathrm{ml}$ of concentrated $\mathrm{H}_{2} \mathrm{SO}_{4}$ was added and inserted into a rack. The mixture of standard sample was placed in a digestion block heater under fume hood, and the exhaust manipulation fold was connected to an aspirator. The mixture was kept in a digester at $420{ }^{\circ} \mathrm{C}$ until the liquid becomes transparent. The rack was removed from exhaust manifold and transferred separately into distillation unit. Distill automatically by adding $65 \mathrm{ml}$ distilled water and $35 \mathrm{ml}$ of $40 \%$ sodium hydroxide solution. The condensed liquid was collected in a cornical flask containing boric acid and titrated against $0.1142 \mathrm{~N}$ sulfuric acid until color turns purple. The crude protein was calculated as;

$\% N=\frac{1.4007 \times(\mathrm{T}-\mathrm{B})}{\mathrm{W}} \times \mathrm{N}$

Where;

$\mathrm{T}=$ volume of acid used for sample titration

$\mathrm{B}=$ volume of acid used for blank

$\mathrm{N}=$ normality of acid

$\mathrm{W}=$ sample weight in grams

1.4007: conversion factor milliequivalent of nitrogen and $\mathrm{N}$ percent.

$\%$ Crude protein can be calculated as;

$\% \mathrm{CP}=\% \mathrm{~N} \times 6.25$

Where 6.5 is a dilution factor for all forages.

\section{Carbohydrate}

The carbohydrate content was determined by difference, that is, addition of fat, crude protein, ash, and crude fiber subtracted from 100\%. This gives the amount of nitrogen-free extract otherwise known as carbohydrate.

$$
\% \mathrm{CHO}=100-(\% \text { moisture }+\% \text { Fat }+\% \text { Ash }+\% \text { Crude fiber }+\% \text { Crude protein })
$$

\section{Energy level.}

The energy level was calculated using the formula;

$$
\text { Energy }(\mathrm{Kcal})=[(\% \mathrm{CHO} \times 4)+(\% \mathrm{CP})+(\% \mathrm{Fat}+9)]
$$

Where; CHO, CP and CL stand for carbohydrate, crude protein and crude lipid respectively.

\section{OIL EXTRACTION}

The method employed was that of solvent extraction with the Soxhlet extractor apparatus as described by AOAC 1990.

A $250 \mathrm{ml}$ Soxhlet extractor apparatus and petroleum ether as solvent were used. A mass of 30 $\mathrm{g}$ of butternut seeds powder was weighed into a muslin cloth which was placed in a Soxhlet 
apparatus thimble. A round bottom flask containing $250 \mathrm{ml}$ of petroleum ether was to the end of the apparatus and a condenser, tightly fixed at the bottom the extractor. The whole set up was heated up in a water bath at a temperature of $60{ }^{\circ} \mathrm{C}$. The excess solvent in the oil was recycled by heating in a heating mantle at a temperature of $60{ }^{\circ} \mathrm{C}$ after the extraction. Quantity of oil extracted was determined gravimetrically. The oil yield (fig 3) was evaluated as the ratio of the weight of the extracted seed oil to the weight of the butternut powder sample (AppendixI) as described below.

$$
\% \text { Oil yield }=\frac{\text { Weight in gram of extracted oil }}{\text { Weight in gram of extracted seed powder sample }}
$$

The extraction process was carried out for six hours and was done in correspondence to the solvent used (petroleum ether at $60{ }^{\circ} \mathrm{C}$ ).

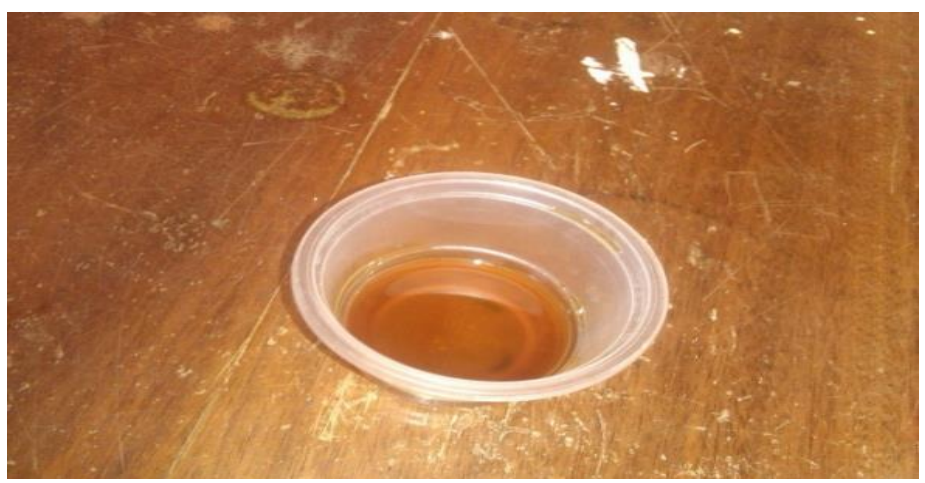

\section{Figure 3: Butternut squash seed oil.}

\section{Physico-chemical properties}

\section{Physical properties}

\section{Color and Odor}

The color of oils describes the physical appearance the oil by sensory evaluation as compared to rainbow Color and the Odor is its smell.

These were done by direct physical observation of the oil and compared to other literature.

\section{pH}

This is the degree of acidity or alkalinity of the oil and it was measured with the $\mathrm{pH}$ meter.

The $\mathrm{pH}$ electrode was standardized with buffer solution and the electrode immersed into the oil sample. $\mathrm{pH}$ and temperature readings displayed on the $\mathrm{pH}$ meter screen were noted.

The experiment was repeated and the average value was taken to be the $\mathrm{pH}$ of the oil at that temperature

\section{Determination of Specific Gravity}

A beaker was placed on a chemical balance and a volume of oil was weighed.

The same volume of distilled water was weighed using another beaker.

The specific gravity was calculated as,

$$
S G=\frac{\text { Measured weight of oil }}{\text { Measured weight of distilled water }}
$$




\subsubsection{Refractive Index}

The refract meter's prism case was opened and four drops of the oil were placed on the bottom of the prism using a plastic pipette.

Visual observations were made the instrument's eyepiece and the prism adjustment was turned until a distinct light or dark border became visible.

The compensator dial was adjusted to remove as much Color as possible from both the light and dark areas. The eyepiece was also adjusted to bring the light or dark border into a sharp focus while adjusting the prism knob to place border in the center of the crosshairs.

The refractive index and the temperature of the oil were read from the scale of the instrument.

\section{Chemical properties}

\section{Acid value}

A mass of $1.0 \mathrm{~g}$ was completely dissolved in $20 \mathrm{ml}$ of ethanol

Using phenolphthalein as indicator, the mixture was titrated against $0.1 \mathrm{M} \mathrm{KOH}$ Solution until a pink Color appeared and persisted for at least 10 seconds.

The experiment was repeated and the average of the titer values was taken.

The acid value was calculated as;

$$
A V=56.1(V N) / M
$$

Where;

$\mathrm{V}=$ Titer value of $\mathrm{KOH}$ used

$\mathrm{N}=$ Normality of the $\mathrm{KOH}$ used

$\mathrm{M}=$ mass of oil used

\section{Free Fatty Acid Value}

The Free Fatty Acid value was calculated as;

Acid Value $\times 0.503^{28}$

\section{Peroxide Value}

A mass of $5.0 \mathrm{~g}$ of the oil was weighed into a conical flask. A volume of $10 \mathrm{ml}$ of chloroform was added and swirled to dissolve the oil.

A volume of $15.0 \mathrm{ml}$ acetic acid and $1 \mathrm{ml} \mathrm{KI}$ solution was added to the content, shaken and left in the dark place for exactly 5 minutes. $30 \mathrm{ml}$ of distilled water was added to the content and the titrated against excess sodium thiosulphate solution. The endpoint was reached when the blue color disappeared.

The experiment was repeated without the oil under the same conditions and was used as the control.

The peroxide value was calculated as;

$P V=100 \mathrm{~N}(\mathrm{VS}-\mathrm{VC}) \div \mathrm{M}$

Where;

$\mathrm{VS}=$ Volume of $\mathrm{Na}_{2} \mathrm{~S}_{2} \mathrm{O}_{3}$ used in the sample titration

$\mathrm{VC}=$ Volume of $\mathrm{Na}_{2} \mathrm{~S}_{2} \mathrm{O}_{3}$ used in control titration 
$\mathrm{N}=$ Normality of $\mathrm{Na}_{2} \mathrm{~S}_{2} \mathrm{O}_{3}$

$\mathrm{M}=$ Mass of oil sample

\section{Saponification Value}

Indicator method was used as specified by ISO 3657(1988). A mass of $2 \mathrm{~g}$ of the sample was weighed into a conical flask; $25 \mathrm{ml}$ of $0.1 \mathrm{~N}$ ethanolic potassium hydroxide was added. The content was constantly stirred and allowed and to boil gently for about 60 minutes. A reflux condenser was placed on the flask containing the mixture. Few drops of phenolphthalein indicator was added to the warm solution and then titrated with $0.1 \mathrm{M} \mathrm{HCl}$ to the end point until a pink of the indicator disappears. The same procedure was used for other samples and the blank.

The expression for saponification value (S.V) (Appendix-VI) is given by;

$S . V=56.1 \mathrm{~N}(\mathrm{~V} 0-\mathrm{V} 1) \div \mathrm{M}$

Where; V0 is the volume of the solution used for the blank test, V1 is the sodium thiosulphate used for the determination, $\mathrm{N}$ is the actual Molarity of $\mathrm{HCl}$ used and $\mathrm{M}$ is mass of sample.

\section{Iodine Value}

The iodine value was determined according to the methods of ISO 3961:1996.

Approximately $0.25 \mathrm{~g}$ of the oil sample was weighed into a $250 \mathrm{ml}$ conical flask. $10 \mathrm{ml}$ of chloroform was added. $30 \mathrm{ml}$ of Hanus solution was added and closed by para film. The mixture was allowed to stand for 30 minutes with continuous shaking. $10 \mathrm{ml}$ of $15 \%$ potassium iodide solution was added and then shook. $100 \mathrm{ml}$ of distilled water was then added. The resulting solution was titrated against $0.1 \mathrm{~N}$ sodium thiosulphate solution till yellow Color formed, then 2-3 drops of starch solution was added where blue solution formed and then continued with the titration until the blue color disappeared (volume of $\mathrm{Na}_{2} \mathrm{~S}_{2} \mathrm{O}_{3}$ at the end point represents $\mathrm{S}$ ). The same above procedure but without sample was done (blank).

The iodine number was calculated by using the formula:

Iodine value $=\frac{(\mathrm{B}-\mathrm{S} \times \mathrm{N} \text { of } \mathrm{Na} 2 \mathrm{O} 3 \times 0.127 \mathrm{~g} / \mathrm{meq}}{\text { Weight of Sample }} \times 100$

$\mathrm{B}=\mathrm{Vml}$ of $\mathrm{Na}_{2} \mathrm{~S}_{2} \mathrm{O}_{3}$ volume for blank

$\mathrm{S}=\mathrm{Vml}$ of $\mathrm{Na}_{2} \mathrm{~S}_{2} \mathrm{O}_{3}$ volume for sample

\section{RESULTS}

The tables below signifie the proximate composition of butternut squash fruits and the physicochemical properties of the seed oil. 
Table 3

Proximate Composition of Dried Pulp, Dried Seed and Defatted Seed Residue.

\begin{tabular}{llll}
\hline Component Analyzed & Dried Pulp & Dried Seed & $\begin{array}{l}\text { Defatted } \\
\text { Residue }\end{array}$ \\
\hline & & & Seed \\
Moisture Content (\%) & $6.17 \pm 0.50$ & $4.00 \pm 0.50$ & $5.16 \pm 0.02$ \\
Liquid Content (\%) & $1.16 \pm 0.16$ & $22.83 \pm 0.17$ & $4.33 \pm 1.88$ \\
Ash Content (\%) & $5.57 \pm 0.27$ & $4.60 \pm 0.30$ & $6.86 \pm 0.05$ \\
Fiber Content (\%) & $3.55 \pm 0.30$ & $1.152 \pm 0.20$ & $5.59 \pm 0.10$ \\
Crude Protein Content (\%) & $10.85 \pm 0.01$ & $33.92 \pm 0.25$ & $49.2 \pm 0.10$ \\
& $72.70 \pm 0.00$ & $33.50 \pm 0.00$ & $28.86 \pm 0.00$ \\
Carbohydrate Content (\%) & & & \\
\hline
\end{tabular}

Values are means of two determinations with $S D \pm t$ wo decimal places

Table 4

Physico-Chemical Properties of Extracted Oil and Oils Found in Literature.

\begin{tabular}{|c|c|c|c|c|c|}
\hline \multirow{2}{*}{$\begin{array}{l}\text { Physico- } \\
\text { chemical } \\
\text { Property }\end{array}$} & \multicolumn{5}{|c|}{ Oil Source (seed) } \\
\hline & *C. pepo & *C. maxma & *Desert melon & $\begin{array}{l}\text { *Water } \\
\text { melon }\end{array}$ & C. moschata \\
\hline Color & NR & NR & NR & L. yellow & L. brown \\
\hline Odor & NR & NR & NR & NR & Pleasant \\
\hline $\mathrm{pH}$ & NR & NR & NR & NR & $6.91 \pm 0.01$ \\
\hline RI & 1.47 & 1.46 & 1.47 & 1.47 & $1.37 \pm 0.00$ \\
\hline $\mathrm{OC} \%$ & 41.59 & 43.69 & 28.00 & 41.32 & $13.31 \pm 0.04$ \\
\hline $\mathrm{AV} \mathrm{mgKOH} / \mathrm{g}$ & $0.78 * * *$ & 0.53 & 2.50 & 2.37 & $3.42 \pm 0.01$ \\
\hline $\mathrm{SV} \mathrm{mgKOH} / \mathrm{g}$ & 190.69 & 185.20 & 182.20 & 183.13 & $15.43 \pm 0.07$ \\
\hline $\mathrm{V} \mathrm{mm} 2 / \mathrm{s}$ & 93.65 & 48.09 & NR & 2.48 & NR \\
\hline IV gI2/100g & 104.36 & 105.12 & 124.00 & 121.51 & $21.08 \pm 0.49$ \\
\hline FFA & $0.39 * * *$ & 0.27 & NR & 6.40 & $1.71 \pm 0.00$ \\
\hline SG & 0.91 & 0.91 & 0.95 & 0.85 & $0.99 \pm 0.00$ \\
\hline $\mathrm{PV} \mathrm{meqO}_{2} / \mathrm{kg}$ & NR & NR & NR & 2.20 & $2.50 \pm 0.02$ \\
\hline
\end{tabular}

***Mean standard deviations in two dimensions.

$\mathrm{AV}=$ Acid Value, $\mathrm{SV}=$ Saponification Value, IV=Iodine Value, V=Viscosity, FFA=Free Fatty Acid, $\mathrm{NR}=$ Not reported, $\mathrm{OC}=\%$ Oil yield, ${ }^{*}$ Are oils found in literature, $* * * 26$.

\section{DISCUSSIONS}

The difference in the moisture content of the dried seed and the defatted seed is as a result of high concentration of defatted seed which is similar to the whole seed (sun dried) of $C$. 
moschata $(5.7 \pm 0.4)$, seed kernel (sun dried) of C.moschata $(5.6 \pm 0.0), C$. maxima whole seed (sun dried) $(5.5 \pm 0.2)^{22}$. The moisture values are lower than that of soya bean $(11.07 \%)$ and coconut seeds, $(14.3 \%)^{21}$. The low level of moisture content of butternut squash seeds enables them to be preserved for long period of time. Moisture levels of food products have a bearing on their dry matter content. The higher the moisture content, the lower the dry matter content;

which would help the food processors to make decisions on the economics of thermal processing $^{22}$. The crude protein of processed samples of fruit and seeds in this study are lower than that of C.moschata fruit without rind $(4.3 \pm 0.0), C$. maxima $(3.7 \pm 0.0)$, and whole seed of. C moschata (sun dried) (35.4 \pm 0.3$)$, seed kernel of C.moschata $(37.4 \pm 0.2)$, whole seed of $C$. maxima (sun dried) $(36.3 \pm 0.2)$ and seed kernel of $C$. maxima $(40.3 \pm 0.3)^{22}$. A difference exists between the dried seed and defatted seed residue which could be as a result of sample preparation method. The protein content of the defatted seed residue could contribute to the protein content in the seed's kernel ${ }^{22}$. An adult male of about $70 \mathrm{~kg}$ body weight requires $35 \mathrm{~g}$ of protein daily, therefore, only $98.93 \mathrm{~g}$ of $C$. moschata would be required to provide minimum daily protein needs. However, $122 \mathrm{~g}$ should be consumed to meet requirements if an allowance of $25 \%$ is made to take care of digestibility and limiting sulphur amino acid ${ }^{20}$. The proteins are globulin type and are deficient in lysine and sulphur bearing amino acids ${ }^{57}$. The results shows that C.moschata seeds from Kukobila in the northern part of Ghana are rich in proteins hence good for children, lactating mothers and old people who need more proteins for growth, maintenance and repair of warn tissues. The crude lipid content of dried seed was within the range of $20-38.00 \%$. This could be classified as an oil seed like groundnut, melon etc. Lipids are essential because they provide the body with maximum energy ${ }^{45}$.

The fiber content of the defatted seed residue was higher than that of the powdered seed which could be as a result of the husk of the seed. The fiber content of the dried seed is $1.15 \%$ which is lower than that of melon $(2.7 \%)^{43}$ but can be compared favorably with that of Cucurbita pepo $L$ seeds $(1.0)^{18}$. Fiber containing foods are known to expand the inside walls of the colon, ease the passage of waste by preventing constipation. It lowers the cholesterol levels in the blood and reduces the risk of various cancers. Emphasis is made on the intake of low fiber in the nutrition of infants and weaning children; high fiber levels in weaning diet can lead to irritation of gut mucosa ${ }^{12}$. It also enhances gut perturbation in young animals (e.g. piglets and (hicken) $)^{19}$.

The Ash content of the dried seeds are similar to that of C.pepo $L$ seed $(5.50)^{18}$ melon $(5.40 \%)$ and the defatted seed residue similar to melon $(7.9 \%)^{43}$. Samples with high ash content are expected to have high concentration of various mineral elements which are expected to speed up metabolic processes, improve growth and development.The carbohydrate content of the dried seed and defatted residue cannot be considered as a potential source of carbohydrate when compared to dried pulp $(72.70 \%)$ and the content of some convectional sources like cereals with $72.90 \mathrm{~g} / 100 \mathrm{~g}$ carbohydrates ${ }^{3}$.

The experimental results in Table 1 showed that butternut squash fruit cultivated at Kukobila has seeds of immerse values. The extracted oil was light brown in color with an average yield of $131 \mathrm{~g}$ of the prepared sample. The percentage yield of the extracted butternut squash seed oil was $13.31 \%$ (Table 1). This value fell in the range reported for different species of cucurbita $(9.8-52.1 \%)^{26}$. In comparison to the oil content of other seeds, the oil content of this study was lower than that of C. maxima (43.69\%), C. pepo (41.59\%) and desert melon (28.0). The difference in oil yield may be as a result of geographical location, specie or variety of fruit, method for sample preparation, size of fruit (in terms of maturity) and other environmental factors. This can be as a result of the husk. The color and odor of the oil is an important feature 
which determines the customers' acceptability for oil products. Butternut squash seed oil has a light brown color with a pleasant smell. The color development is due to the presence of pigment such as chlorophyll, carotenoids etc. Removal of such coloring pigment is an important task from commercial view point. Bleaching can be used to remove the color of oils and fats during processing ${ }^{12}$.

The refractive index of C.moschata was 1.3692 which is closer to that of pumpkin seed oil; C.pepo (1.4662), C.maxima (1.4652) and desert melon (1.468). It is independent on the variety of pumpkin seed oil and it's not as thick as most drying oils whose refractive indices fall between $1.475-1.485^{5}$. Correspondingly the effect of variety was not significant on the specific gravity of pumpkin seed oil. The specific gravity (0.997) in this study does not differ much from C.maxima (0.913), C.pepo (0.915) and Desert melon (0.954).

The saponification value of Cucurbita moschata was (15.43) which is far lower than that of $C$. pepo (190.69), C. maxima (185.20) and desert melon (182.1). This indicates that butternut squash seeds oil is not a good raw material for soap industries. Saponification value is inversely proportional to the average molecular weight or chain length of the fatty $\operatorname{acid}^{38}$. Therefore, the shorter the average chain length $\left(\mathrm{C}_{4}-\mathrm{C}_{12}\right)$ the higher the saponification number ${ }^{51}$. The value obtained from this study shows that it contains high amounts of long chain fatty acids $\left(>\mathrm{C}_{12}\right)$, which is lower than the regulation of codex standard permissibility level (CODEX-STAN2101999) (190-209 mg KOH/g).]The Acid value (0.34) of Cucurbita moschata was lower than that of $C$. pepo (0.39), C. maxim (0.53) and desert melon (2.5) indicates that cucurbita moschata contains less Free Fatty acid thus reducing its susceptibility to rancidification or deterioration. It is a measure of the extent to which triglycerides in the have been decomposed by lipase action into free fatty acids; acid value depends on the degree of rancidity which is used as an index of freshness ${ }^{42}$. The low acid value suggest that the oil is suitable for paint and ink production and edible as well. The low free fatty acid value (1.71) indicates that butternut squash seed oil is of good quality ${ }^{2}$.

The peroxide value of the extracted oil was 2.5 meq $\mathrm{O}_{2} \mathrm{~kg}^{-1}$; indicating good oxidative stability of the oil. Comparing with that of watermelon seed oil $\left(2.2\right.$ meq $\left.\mathrm{O}_{2} \mathrm{~kg}^{-1}\right)$, butternut squash seed oil is higher than watermelon seed oil ${ }^{28}$. Peroxide value is as a result of changes the fat undergo during storage; emission of unpleasant odor and taste (rancidity). The results obtained from the study shows that butternut squash seed oil is fresh and does not easily undergo rancidification during storage ${ }^{46}$ oils with peroxide values ranging between 20.0-40.0 easily undergoes rancidification ${ }^{4}$.The iodine value of the extracted oil was $21.082 \mathrm{mg} \mathrm{I}_{2} / 100 \mathrm{~g}$ which is lower than C.pepo (104.36), C.maxima (105.12) and desert melon (124.0). This result suggests that butternut squash seed oil is not suitable for biodiesel production when compared with the other varieties of pumpkin seed oil. Low iodine value of vegetable oil produces biodiesel with high cloud and pour points; higher cloud and pour points means poor engine performance at cold temperatures. Similarly, oils with iodine value less than $100 \mathrm{~g} \mathrm{I}_{2} / 100 \mathrm{~g}$ are non-drying oils and have lesser number of unsaturated bonds; lower susceptibility to oxidative rancidity. This nondrying attribute is a good fuel property which indicates the oil's resourcefulness as feedstock for biofuel production.

\section{CONCLUSION}

The high oil content of the seed of butternut squash coupled with fairly low acid value makes it suitable as edible oil, a food complement and suggests its suitability for the production of paints, inks and others. Butternut squash seed oil is not suitable for soap and biodiesel production; due the low iodine and saponification values. The seeds are highly nutritious; rich 
in protein which is good for children, lactating mothers and old people who need more protein for growth, maintenance and repair of warn tissues.

\section{RECOMMENDATION}

In order to prevent post-harvest loses, butternut squash fruits which are rejected before exportation can be used to prepare animal feed or used as a meal supplement for livestock. Further research should be carried out to convert Butternut squash into breakfast meals and baby feeds due to its high protein content and gluten free nature

\section{REFERENCES}

1. Achu, M.B., Fokou, E., Tchiegangc, Fotso, M., and Tchouanguep, F.M. (2005). Nutritive value of some cucurbitaceae oilseeds from different regions in Cameroon. African Journal of Biotechnology, 4 (11):1329-1334.

2. Adejumo, O.A., Balarin, F.M., and Farounbi, A. (2014). Characterization of Ogbomosho Mango seed oil. National Center for Agricultural Mechanization, Idofian, Ilorin. Proceedings of the International Soil Tillage Research Organization (ISTRO) Nigerian, Akure, 144-148.

3. Adewusi, S.R.A., Udio, A.J., and Osuntogun, B.A. (2012). Bread Fruit (ArtocarpuscommunisForst) from South-western Nigerian Starch Nutrition. 85: 285294.

4. Ajayi, I.A, Adewuyi, A., and Oderinole, R.A. (2009). Characterization of seed and seed oil of huracrepitans and kinetics of degradation of oil during heating. EJEAFC. Electronic Journal of Environmental, Agricultural and Food chemistry, 8(3) 201- 208.

5. Akinhanmi, T.F., Akintokun, P.O., and Atasie, V.N. (2008). Chemical composition and physico-chemical properties of cashew nut. Journal of Agricultural Food and Environmental science, 2, 4-8.

6. Akpan, U.G., Jimoh, A. and Mohammed, A.D. (2007). Extraction, Characterization and Modification of Castor Seed Oil. Department of Chemical Engineering, Federal University of Technology, Minna P.M.B. 65, Niger State.

7. Alabama, A. (2013). Guide to commercial pumpkin and winter squash production; Alabama Cooperative Extension System ANR-1041, Alabama A \&M and Auburn Universities.

8. Aremu, M.O., Olaofe, O. and Akintayo, T.E. (2006). A Comparative study on the chemical and amino acid composition of some Nigeria under-utilized legume flours. Pak.J.Nuhr. 5:34-35.

9. Backyard Vegetable gardening (2014).Growing Butternut Squash. Retrieved $27^{\text {th }}$ September, 2014 from http://www.backyard-vegetable-gardening.com.problems-ofbutternut.html

10. Bauer, J. (2014). Food cures: How food affects Arthritis. Retrieved from; www.joybauer.com/arthristis/how-food-affects-arthritis.aspx.

11. Bayly, M. (2012). Butternut Seed Nutrition. Retrieved from http://www.livestrong.com/article/270654-butternut-squash-nutrition/\#page=1 of

12. Bello, M.O., Farade, O.S., Adewusi, S.R.A and Olawore, N.O. (2008). Studies of some lesser known Nigerian fruits. African Journal of Biotechnology, 7 (1):3972-3979.

13. Betiku, E. and Adepoju, T.F. (2013). Sorrel (Hibiscus Sabdariffa) seed oil Extraction, Optimization and Quality characterization; American Chemical Science journal, 
3(4):449-458, Biochemical Engineering laboratory, Department of Chemical Engineering Obafemi Awolowo University. Lie-life 220005, Osun state, Nigeria.

14. Brain, H. (2008). Utilization of Squash Waste. Bachelor of Technology (Honours) in food Technology, Massey University, Palmerston North, New Zealand,196-199.

15. Cerkauskas, D.R. (2000). Insects, Diseases and Disorders of Asian vegetables. Ontario, Ministry of Agriculture, Food and rural Affairs. Retrieved $27^{\text {th }}$ September, 2014 from http://www.omafra.gov.on.ca/english/crops/facts/00-095.html

16. Dimberu, .G. and Belele, B. (2008). Estimation of Total free fatty acid and cholesterol content in some commercial edible oils in Ethiopia, Bahir DAR-Department of Chemistry, college of science Bahir Dar University, Bahir Dar, Ethiopia, 2(8):134-138.

17. DIN51 757(1994). Testing of mineral oils and related materials: Determination of density.

18. Elinge, C.M., Muhammed, A., Atiku, F.A., Itodo, A. U., peni, I.J., Saani, O.M., and Mbongo A.N. (2012). Proximate, Mineral and Anti-nutrient composition of pumpkin (Cucurbita pepo L) seeds extract 32: 103-105.

19. Eromosele, J.C., Eromosele, C.O. and Kuzhkuzha, D.M. (1991). Evaluation of mineral elements and Ascorbic Acid Contents in Fruits of some wild plants. Plant Food for Human Nutrition 41:53-57.

20. Fagbemi, T.N. and Oshodi, A.A. (1991). Chemical composition and functional properties of full fat fluted pumpkin seed flour. Nigerian Food Journal 9:26-32.

21. FAO (1982). Food composition Table for the Near East. Nuts and seeds. FAO Food and nutrition paper 26 ISBN 92-5.10177-6P.85.

22. Fedha, M.S., Mwasaru, M.A., Njoroge, C.k, Ojijo, N.O and Ouma, G. O. (2010) Effect of drying on selected proximate composition of fresh and processed fruits and seeds of two pumpkin species. Agriculture and Biology Journal of North America, Kenya.

23. FAO/WHO (2009). Report of $21^{\text {st }}$ session of the Codex Alimentarius Committee on fats and oils. Kola kinabalu, Malaysia.

24. Flint, M.L. (1998). Pests of the Garden and small farm; a grower's guide to using less pesticides. Oakland: University of California. Agricultural National Research Publication 3332.

25. Glenn, E. (2014)."Viscosity". The physics Hypertexbook. Retrieved from; http//:www.en.m.wikipedia.org/wiki/Viscosity.

26. Gohari, A., Ardabil, R. and Khoda, M.H. (2011). Chemical composition and physicochemical properties of pumpkin seeds (Cucurbita pepo subsp.pepo Var. Styriaka) Grown in Iran. Journal of Agricultural Science Technology, Vol.13:1053-1063.

27. Grubben, G.H.J \& Chigumira, N.F. (2004). "Cucurbita moschata Duchesne" Prota: 2 Vegetable/legumes Record Display. Retrieved 24 ${ }^{\text {th }}$ September, 2014 from http://www.database.prota.org/PROTAhtmi/Cucurbita\%20moschata_En.html

28. Ibeto, C.N., Okoye, O.B. and Ofoefule, A.U. (2012). "Comparative Study of some oils as potential feedstock for Biodisel production ISBRN Renewable Energy" 621518; 5402.

29. IITA (1988). Selected Methods for soil and plants Analysis (Manual Series No_ 1) International Institute for Tropical Agriculture, Ibadan Nigerian, Pp. 55-56.

30. Karoly, D. (2011). Proximate analysis of foods and Modern analytical methods. Retrieved

from, 
www.tankonyvtar.hu/en/tartalom/tamop425/0010_1A_Book_angol_04_takarmanyoza stan/ch03.html.

31. Kerns, M. (2012). The advantages of Butternut Squash; Demand media. Retrieved from;

www.healthyeating. Sfgate.com/genpage.php?tname=foodspiceadbid=63,"theworld's .

32. Kerns, M. (2007). Demands Media. Advantage of Butternut Squash. Received $20^{\text {th }}$ September, 2014 from http://www.healtheating.Sfguide.com.benefits-of-butternutsquash-6962.html

33. Kunyanga, C. (2008).Development of Porridge from Sorghum-Cassava flour enriched with Butternut flour; Department of food science, Nutrition and Technology. BSc. Food science, Nutrition and Dietics, 146-155.

34. Kyari, M.Z. (2008). Extraction and Characterization of seed oils. Int. Agrophysics, 22,139-42.

35. MaCain, A.H. (1994).Powdery mildew. Hortscript \#3, University of California Cooperation Extension. Marin County.

36. Maxwell K.B. (2008). The effects of Butternut Squash on the incomes of small-holders in Suba District, Kenya. African journal of Agricultural Science, 4 (5):319-324.

37. Mort, R. (1996) Olives: The life and Love of a Noble Fruit, North Point Press, and ISBN 0-86547-503-2.

38. Muhammed, N., Bamishaiye.E, E., Usman L., Salawu, .M, Nafiu, .M, and Oloyede, O. (2011). Physico-chemical properties and Fatty Acid Composition of Cyperus esculentus (Tiger Nut) Tuber Oil.Biores. Bull, 5:51-54.

39. Natalie, A.K. (2011). The healthiest foods are most Nutrient Dense; enjoy every food in every way. Retrieved from;http://www.hobby_exchange.freehostia.com/myDiet_01Squashhw.html.

40. Nouvell, K. (2014). Facts on Health Benefits of Squash. Retrieved from, www.livestrong.com/article/2701-f-h-b-s/\#page=1.

41. Nwabanne, J.T. (2012). Kinetics and Thermodynamics Study of oil Extraction from fluted pumpkin seed; Department of Chemical Engineering, Nnamdi Azikiwe University, P.M.B 5025, Awka, Nigeria.

42. Ojieh, .G. A, Oluba, O., Ogunlowa, Y., Adebisi, K., Eidange, .G. and Orole, .R. (2007). Compositional Studies of Citrullus lanatus (Egusi melon) Seed. The Journal of Nutritional and Wellness, Volume 6 Number 1.

43. Oladimeji, G.R. and Kolapo, A.L. (2007). Evaluation of proximate changes and microbiology of stored defatted residues of some selected Nigerian Oil seeds. Department of Biology, the polytechnics of Ibadan, Nigeria. African Journal of Agricultural Research, Vol.3 (2), pp.126-129.

44. Olumole, S.I, Adeoti, A. and Oluwaseum, A. (2013). Comparative study on nutrient composition, phytochemicals and functional characteristics of raw, germinated and fermented Moringa olufera seed flour.

45. Oluyemi, E.A., Akilua, A.A., Adenuya, A.A. and Adebayo, M.B. (2006). Mineral content of some commonly consumed Nigerian Foods. Science focus.11 (1):153-157.

46. Palumbo, M. and Linda, J. H. (2011). Microbiological Food Safety of Olive Oil: A review of the Literature, University of California, Davis. 
47. Park, K. (2007). A water soluble extract from Cucurbita moschata shows anti-obesity effects by controlling lipid metabolism in a high fat diet-induced obesity mouse model. Biochemistry Biophysics Restitution Communication, 359(3):419-25.

48. Rayees, B., Dorcas, M. and Chilia, S. (2013). Nutritional Composition and Oil fatty acids of Indian Winter Melon Seeds. International Food Research Journal, 20(3):11511155(2013).Department of LSTF, Central food Technological Research Institute Mysore-570020, Indian.

49. Salam, R. (May 2013). Joy News, M.C Modern Ghana." Minister Tasks District Assemblies in UW to promote the cultivation of Butternut Squash. Retrieved $24^{\text {th }}$ September, 2014 from http://www.mordernghana.com/mobile/463578/1/ministertasks-task-district-assemblies-in-UW-to-promot.html.

50. Secrest, R. (1996). How products are made; Volume 3, University of Saskatchewan College of Agricultural Sciences.

51. Tamzid, H.M., Alam, M.T. and Islam, M.A.U. (2007). Physico-chemical and nutritional studies of Terminalia belerica roxb. Seed Oil and seed kernel. J. bio-Sci., 15: 117-126.

52. Tara, A. (2012). The health benefits of Butternut Squash. Retrieved from;http//:www.fullcircle.com/goodfoodlife/2012/07107-ways-squash-can-improveur-heath.

53. Thomas, A. Z. (2010). Fruit rots of squash and pumpkins; Department of plant pathology Cornell University.

54. Umass, M. (2014). Soil crop and pest management; Umass Extension, National Institute of Food and Agriculture.

55. Umesh, L. (2009). Power to your diet. Retrieved $24^{\text {th }}$ September, 2014, from http://www.nutrition-and-you.com.

56. Vietnam (March 21). Food in every country. Retrieved $20^{\text {th }}$ September, 2014 from http://www.foodbycountry.com/Spain-to-Zimbabwe-Cumulative-

Index/Zimbabwe.html

57. Vodoule, S.R and Capo-chichi, L. (1998). High protein crop with multiples uses but neglected and underutilized. Bulletin-CIEPA/West African cover crops / cotonon, Republic of Benin page 6.

58. Wikipedia (2014). Butternut Squash. Retrieved 22 $2^{\text {nd }}$ September, 2014 from http://www.en.mwikipedia.org/wiki/Butternut_Squash.Soil

59. Willets, S. (2012). Acid-base and pH notes. Retrieved from, https://sites.google.com/site/fhsscience-hw/acids-bases-and-ph-note 